Under this proposal, ACRL members will pay annual dues of $\$ 50$, giving them all rights and privileges afforded ALA members and all rights and privileges afforded ACRL members. The divisional fees will go directly to the divisions for their own use.

A substitute dues proposal presented by the American Association of School Librarians was similar in concept to the COPES plan but lower in actual fees. Under that proposal, members would have paid a basic fee of $\$ 35$, which would have included membership in one division. Of the $\$ 35, \$ 15$ would have gone directly to the division for its own use. The AASL proposal was similar to the one presented by ACRL at the Las Vegas meeting. Bernard Franckowiak, president of AASL, called the COPES proposal "a guaranteed annual wage" for central ALA headquarters personnel, since approximately 40 percent of the current ALA budget supports the administration and operations of central ALA. ACRL supported the AASL proposal, but the two divisions were unable to muster enough votes in Council to pass the AASL proposal.

ACRL and AASL both stand to gain under the COPES proposal, since for the first time in several years divisions will have fiscal autonomy. Both divisions pledged to work for the re- duction of the enormous overhead costs at headquarters.

The ALA Council was charged by some members of the association with being fiscally irresponsible, since in recent years Council has passed policies which also mandate expensive methods of implementation. It was argued during debate on the floor of Council that the ALA Executive Board should refuse to implement policies that ALA cannot afford. The Executive Board gave every indication that it would accept that responsibility in the future. The draft ALA policy on equal employment opportunity, brought forward to Council for adoption during the meeting, was amended to exclude methods of implementation. ACRL supported the amendments.

Few social issues were considered by Council during the Midwinter Meeting. Council refused to admit to its agenda a resolution supporting the impeachment of President Nixon.

The power struggle between the divisions and central ALA continues, with increased strength being given to the argument that there are some matters that concern all librarians and some that concern librarians in different working environments, i.e., in different types of libraries. Clearly, the COPES dues proposal supports the argument for the decentralization of authority and power.

\title{
Captain Serves New Jersey Academic Libraries
}

A centralized computer operation will order, receive, process, and catalog books for the academic libraries of New Jersey under a program being developed by Captain Library Services Corp., a newly formed nonprofit educational corporation here.

The outgrowth of three years of cooperative effort by Rutgers University, the eight state colleges, and the New Jersey Department of Higher Education, the program as it matures should provide better service to library patrons and increased efficiency in library operations, according to Jay $\mathrm{K}$. Lucker, associate university librarian at Princeton, who heads the board of the new corporation.

Serviced initially by Captain (ComputerAided Processing and Terminal Access Information Network) will be the libraries on the various Rutgers campuses and libraries at Stockton State College and William Paterson College. Other units of the state system are expected to join in the future. Funded by the state Department of Higher Education, the program was developed by IBM in cooperation with Rutgers and has been in operation on the Rutgers campuses since last spring.

When a member library wants to order a book, it processes an order request through a computer hookup with Rutgers' Alexander Library here. The system then orders the book from the publisher, encumbers the funds, receives, catalogs and processes the book, and returns it to the ordering library ready for shelving, together with a set of catalog cardsthus eliminating a great deal of duplication.

Officers of the corporation, in addition to Lucker, are Secretary Fleming Thomas of Burlington County College, president of the TwoYear Colleges Library Association of New Jersey, and Treasurer Mrs. Virginia Whitney, Iibrarian at Rutgers.

A nineteen-member advisory council, representing both public and private college interests, is being formed and a full-time executive director will be hired to administer the project. 